\title{
The Theological and Exegetical Interpretations of John 14:12 and its Contextualization
}

\author{
Dr. Ekundayo, Lawrence Olabode \\ Department Of Religion and African Culture \\ Faculty of Arts, Adekunle Ajasin University, Akungba-Akoko, Ondo State, Nigeria.
}

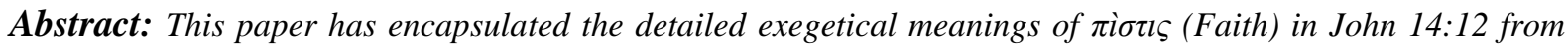
both the Old Testament and New Testament understandings. The paper went further to enunciate the theological meanings of the two promises of Jesus in John 14:12. The paper having analyzed the elements of faith,

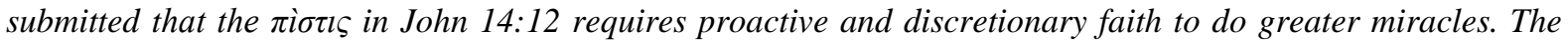

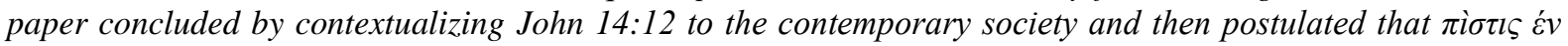
'I
\end{abstract}

Keywords: Exegesis, Faith, Jesus, Proactive, Discretionary.

\section{Introduction}

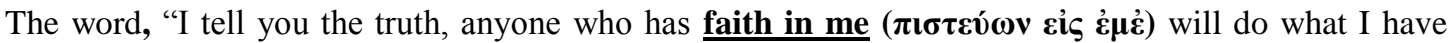
been doing. He will do even greater things than these" is a statement made by Jesus in reaction to the request of Philip that Jesus should show him the Father. Jesus expected that Philip, having followed him for a long time ought to have known that Jesus is in the Father and the Father is in him. Jesus called on Philip to believe in the miracles he performed as evidence of his Godhead.

חìotı s is defined in Hebrews 11:1b as "being sure of what we hope for and certain of what we do not see." By this definition, $\pi$ ì $\tau \iota \varsigma$ is the firm persuasion that comes from full acknowledgement of God's ability or truth (United Church, 2013). Faith is a strong belief without asking for a proof (Mary, 2010). Faith is not just a positive thinking or feeling but it is something always exercised toward God through Jesus (David, 2013).

Eph. 2:8 emphasizes the gift aspect. While Paul teaches that faith must reflect on the intellect, the heart, will and on behavior, James believes that faith must reflect in good works (James 2:26) (New Dictionary of Theology, 1988). In short, "faith is accepting what God has revealed about himself in Jesus and also yielding to Jesus in the light of what he has revealed (Robin, 1983).

\section{The Theological Interpretations of John 14:12}

There are two promises in John 14:12. The first one is "anyone who has faith in me will do what I have been doing". This suggests that the disciples will have power over nature in the same proportion with Jesus. However, the exercise of the power will "be in communion with the living Saviour" (Bruce, 1986). The manifestation of this was clearly seen in the ability of the disciples to replicate the miracles of Jesus. Jesus had healed a "woman which had an issue of blood" with a touch of the fringe of his garment (Mk.5:43) and Paul achieved miracle equality with Jesus by healing the sick with his handkerchiefs and aprons (Acts 19:11-12). Jesus healed the Centurion's servant with a word (Mat.8:8) and Peter recorded miracle equality with Jesus by healing the infirm with his shadow (Acts 5:10-15). Also, Jesus raised Lazarus from the dead (John 11:41b) and Peter had miracle equality with Jesus by bringing Dorcas back to life (Acts 9:40). It is, therefore, clear that Jesus has "enabled them to do such works as he had done" (Matthew Henry, 1992).

The second promise "he will do even greater things than these" means that the disciples through the influence of the Holy Spirit would spread the gospel beyond the Palestine to the whole world (Bruce, 1973). The universal proclamation of the gospel began with Stephen's martyrdom. It was the persecution of the Jerusalem Church that forced the believers to scatter all over and "those who had been scattered preached the word wherever they went" (Acts 8:4). With the exit of Jesus and the arrival of the Holy Spirit the disciples entered a new kingdom of grace where the power of darkness would not be able to frustrate them. Rather, they would "obtain greater victories by the gospel than had been obtained while Christ was upon earth" (Matthew Henry, 1992).

The second promise shows that Jesus power is transmutable. Jesus has the capacity to empower those who believe in him to do greater things. However, "greater things than these" does not mean that the disciples' miracles would be of more exalted glory and influence than that of Jesus because one cannot be stronger than 
the power of his strength. Therefore, the second word of Jesus was not a promise of greater miracles but a prediction of greater extent of the gospel propagation after the ascension.

After the Lord's ascension, the disciples realized the fulfillment of Jesus' promise. The scenes of the crucifixion, resurrection, and ascension of Christ were a living reality to the disciples. They saw that the prophecies had beenliterally fulfilled. They searched the scriptures, and accepted their teachingwith a faith and assurance unknown before (White, 2002).

In conclusion, "greater things than these" is a statement for the post-resurrection period and the activities of the disciples in the book of Acts is an evidence of its fulfillment. Also, the worldwide spread of Christianity is a further sign of these "greater things". John 14:13-14 shows that prayer is the channel between the promise and the fulfillment (New Bible Commentary, 1997).

\section{The Exegeses of John 14: 12 from the Old Testament background}

John 14:12 from the Old Testament background means a complete self-abandonment by which people no longer rely on their own strength and wisdom but in God. In the Old Testament we have people whose pneumatic organs (heart, spirit, mind and soul) were controlled absolutely by faith. Some of these men include:

3.1. Moses. The faith of Moses was very strong that even when his Jewish people saw destruction (with Red Sea in the front and Pharaoh armies behind) Moses saw victory and deliverance, saying: "Do not be afraid, stand firm and you will see the deliverance the Lord will bring you today. The Egyptians you see today you will never see again" (Ex. 14: 13-14).

With this statement of faith, Moses proposed for God to perform four unprecedented miracles:

i. God created a passage on the sea without a bridge. God divided the sea into two walls of water and a dry ground for the Israelites to pass. In this, God manifested himself as the creator (Gen. 1: 6-7).

ii. Angel changes positions and functions from being a guide in the front to a guard at the back (Ex.14:19).

iii. The pillar of cloud that was providing shade for them to travel in the day changed position and function to become a pillar of light for the Jews and a pillar of darkness for the Egyptians (Ex. 14: 19b).

iv. God retarded the movement of the Egyptians armies causing the wheel of their chariot to fall off (Ex. 14: 25).

The faith of Moses made him optimistic, courageous, supportive and selfless. He chose to be ill-treated along with his people rather than stay in the palace for pleasures (Heb. 11: 24-28).

3.2. David was another icon of faith: His faith made him a man of tremendous visualization. While David's kinsmen saw Goliath as a dreaded champion, David in his visual eyes saw him as a mere vanquished and by faith he pronounced God's judgment on Goliath that: "This day the Lord will hand you over to me. I will strike you down and I will cut off your head" and God established David's verdict given in faith. (1Sam.17: 45-47). David demonstrated an unusual faith by picking five mystical stones that symbolize five different authorities and powers:

i. The first stone symbolizes God the Father (1sam. 17: 45b). He brought God into the situation by saying: "The LORD who delivered me from the lion and bear will deliver me from this philistine" (1Sam. 17: 37a). He stood on the stone of the previous success and divine assurance to fight Goliath (1sam. 17:36).

ii. The second stone symbolizes God the Son. This is the stone of prayer and absolute faith in the Lord. "David strengthened himself in the Lord." (1Sam. 30: 6). He took God the Son as his strength, fortress and refuge in that moment of trouble (Psalm 59: 16). King Saul who did not have the faith to step forward also prayed for him. (1sam. 17: 37b).

iii. The third stone symbolizes God the Holy Spirit. David invoked God's Spirit whom the uncircumcised person has come to defile. David was determined to prove to the whole world that the God of Israel is holier and stronger than any god. (1Sam.17: 46c). This God is invisible Spirit and does not fight with physical objects. "All those gathered here will know that it is not by sword or spear that the LORD saves." (1Sam. 17: $47 \mathrm{a})$.

iv. The fourth stone symbolizes the kingship i.e. the authority of Saul who has become dismayed and terrified before Goliath for forty days (1Sam. 17: 11, 16). David being the future king has come to relieve the present king so that the foundation of the throne will not be destroyed. That Saul dressed David was a symbolic investiture and transfer of authority from the old and faithless king to the future king who is faithful and courageous. "Then Saul dressed David in his own tunic. He put a coat of armour on him and a bronze helmet on his head," which indicates a change of power (1Sam. 17: 38).

v. The fifth stone symbolizes the authority of (Abner) the commander of Israel's armies whose position and power has been relegated and ridiculed (1Sam. 17: 10). David therefore, laid a stone of restoration of power and courage of the commander who Goliath has cowed to submission.

The supremacy of God manifests when David has only invoked the first of the five authorities (God the Father) and Goliath fell (1Sam. 17: 45). In short, "through faith David conquered kingdoms, administered justice and gained what was promised" (Heb. 11:33). 
3.3. Abraham was another icon of exceptional faith. His heart and mind was always willing to obey God's instructions no matter how difficult. God subjected him to trial and tribulation by asking him to sacrifice his only son as a burnt offering to him (Gen. 22: 2). Consequently, Abraham put Isaac, a boy of 25 years, on a journey that would end his life and did not tell his wife about it because he believed that in every tribulation there is the preservation of jubilation and in every gory situation there is the reservation of glory. For this reason, when Isaac suspiciously asked him for the lamb for sacrifice, Abraham faithfully proposed that "God himself will provide" (Gen. 22: 7). This statement of faith spurred God to intervene through four miracles viz.

i. At the moment of slaying Isaac God provided a ram as a substitute (Gen. 22: 13).

ii. God promised to multiply the only child to become as numerous as stars in the sky and sand on the seashore (Gen. 22: 17).

iii. God changed Abraham's destiny from a nomad to a man of landed gentry (Gen. 22:17b).

iv. God instituted him as the source of blessing to the mankind (Gen. 22: 18).

The statement Abraham made that "God himself will provide" was prophetic and figurative and indeed God reprieved Isaac back from death (Heb. 11: 19).

3.4. Joshua was another icon of faith. His faith made him the highest type of the devout warrior and a reliable massager that when other spies saw the Jewish nation as weaklings (like grasshoppers) he saw them as valiant people (Num.13:8). His heroic faith and his accomplishment made him to be regarded as a type of Christ (Heb. 4: 8). Through the exercise of faith nature and cosmic luminaries bowed to his order. "The sun stopped in the middle of the sky and delayed going down about a full day. There has never been a day like it before or since, a day when the Lord listened to a man" (Joshua 10:13b-14). Joshua automatically deleted a day from human calendar. This day is presumed to have been lost from February.

\section{The Exegeses of John 14:12 from the New Testament Background}

When John 14:12 is abridged to read: "Anyone who has faith in me ... will do even greater things than these" it refers to two basic concepts of faith, which are discretionary and proactive faith.

4.1. Discretionary faith: This is the faith that brings miracles through the personal judgment and initiative of the believer. It is subject to the spiritual ability of the person involved to initiate the appropriate action required for solving the problem being faced. The believers with discretionary faith have abilities to propose for God to act base on their absolute faith and trust in Jesus. Their faith will always challenge God to intervene. Examples of people of discretionary faith are:

4.1.1. The Centurion (Mat. 8: 5-13). The centurion informed Jesus that his servant was sick at home, Jesus agreed to follow him home. The centurion took a discretionary step by suggesting to Jesus to send a word to his servant at home. This discretionary faith of the centurion astounded Jesus and he said: "I have not found anyone in Israel with such a great faith" and Jesus said "Go it will be done just as you believed it would" (Mat. 8: 10, 13).

4.1.2. Another example of discretionary faith was the woman with an issue of blood (Mk. 5: 25-34). The process that led to the healing of the woman which had an issue of blood was basically her own initiative. She did not seek the counsel, opinion or advice of anyone. She decided with faith that: "If I just touch his cloak I will be healed" (Mk. 5: 28) and by her discretionary action of faith, "immediately her bleeding stopped" (Mk. 5: 29) after 12 years of no discretion.

The faith that can make anyone to do greater things needs a lot of discretions. That is why Solomon said: "Discretion will protect you and understanding will guard you (Pr.2: 11). In fact, understanding, vision and mission are syntheses that revolve on the orb of discretion. For the contemporary church and the Christian body to do greater things like the early Church they must grow on discretionary faith.

4.2. Proactive Faith: The second concept of faith which is required in John 14:12 is Proactive faith. This kind of faith controls situations by making things happened rather than waiting for things to happen and then reacting to them. Proactive faith is not procedural or liturgical. It does not operate on any stereotypical order of worship. It is always spontaneous, creative and imponderable like the case of the paralytic in Mk. 2:1-5. The proactive faith of the 4 men that carried the paralytic overcame two difficult barriers to get the sick man over to Jesus. First, when the 4 men encountered crowd barrier they climbed the roof. Secondly, when they met the roof barrier they dug through it and lowered the paralytic down on top of Jesus. Their proactive faith catches the attention of Jesus who immediately rewarded the paralytic with healing (Mk. 2: 5).

\section{The Elements of Faith}

Proactive and discretionary faith reflects in the thinking, perception, action and projection of people and it manifests certain elements. When these elements of faith have grown to high spiritual level in any person it will be easy for that person to be obedient, to love, to be hopeful and courageous. These elements of faith include the following: 
5.1. Obedience: "The general concept of obedience in the Bible relates to hearing or harking to a higher authority" (Mary, 2014). Faith is the root of obedience and obedience is the fruit of faith. It is faith that enables a person to abide. Obedience is always motivated by faith. Jesus Christ is the perfect model of obedience and he becomes the source of eternal salvation for those who obey (Heb. 5: 8-9).

5.2. Love: While faith motivates obedience, obedience proves our love for God. "Loving God is equated with obeying his words" (Cooper, 2013). John 14:15 says "If you love me, you will keep my commandments." Also, 2 John 6 says, "And this is love that we walk according to his commandments." Christian love for God flows from the heart of gratitude for the unmerited grace received from Jesus Christ. Lack of love for God and our neighbours is the product of faithlessness.

5.3. Hope: "Hope is faith in seed form and faith is hope in final form" (Faithmechanic, 2013). Hope and faith are inseparable substances (Heb.11:1). While hope believes you will receive your desire one day, faith believes you can receive it now. Hope is the possibility, faith is the certainty. Faith transforms hopes to realities (Faithmechanic, 2013).

5.4. Courage: The offspring of faith is courage. It is faith that gives strength to courage and without faith courage cannot stand. Faith gives people the courage to stand for their beliefs. Faith removes fear and installs courage in a misty and challenging situation. It is necessary to know that Christian courage emanates from faith and God is the reason for such courage. That is why in the Bible God always gives himself as the reason to have courage in every situation (Gen. 15:1, 21:17, Isaiah 41:14, Lk.1:30).

5.5. The Holy Spirit: The most inseparable element of faith is Ayto $\pi v \varepsilon v \mu \alpha$. Faith is the habitation of the Holy Spirit. A faithless person is unfit for Holy Spirit habitation. The Holy Spirit can only indwell a faithful person. Ayı $\pi v \varepsilon v \mu \alpha$ is the actual $\delta v v \alpha \mu \iota \varsigma$ that operates with $\pi \iota \sigma \tau 1 \varsigma$ (Rom. 5: 5). Holy Spirit is the agent and instrument that executes the functions of faith.

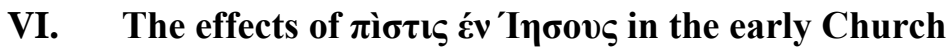

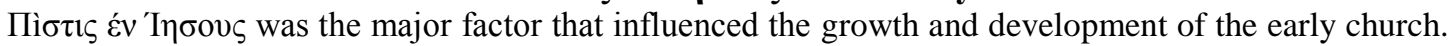

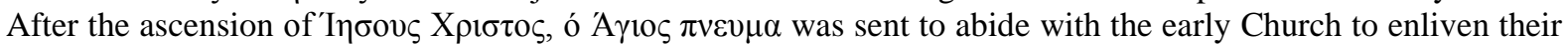

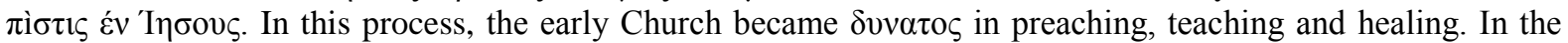

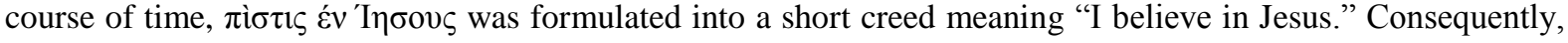
"I believe in Jesus" became the permanent Church's creedal statement for admitting new converts and also for

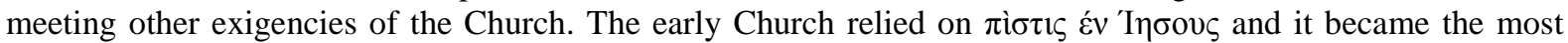
essential requirement for receiving and performing miracles. Miracles performed through the instrument of

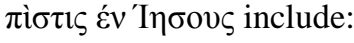

i. The crippled beggar at the temple gate who was expecting silver and gold from Peter but received healing

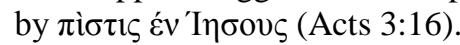

ii. Aeneas of Lydda who has been paralyzed for 8 years was made to walk immediately Peter introduced $\pi \dot{\mathrm{i} \sigma \tau \iota \varsigma}$

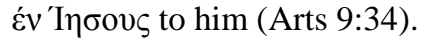

iii. The crippled of Lystra who was lame from birth came in contact with Paul and when Paul "saw that he had $\pi$ ì $\tau \iota \varsigma$ to be healed" he restored him to his feet and began to walk (Arts 14:9).

iv. The demon possessed slave girl in Philippi was exorcised by Paul with the name of Jesus (Arts 16:18).

v. The prison foundation was shaken, its doors opened, chains were broken and the jailer was converted

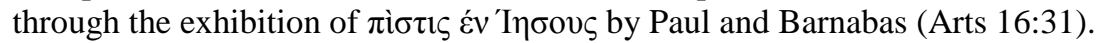

However, the invocation of Jesus' name without $\pi i \sigma \tau \iota \varsigma$ Év 'I $\eta \sigma o v \varsigma$ is invalid and can be spiritually dangerous as evidenced in the case of the seven sons of Sceva who invoked the name of Jesus to exorcise evil spirit. But were fatally wounded by the demon possessed man (Arts 19:16).

\section{The Contextualization of John 14: 12 to the Contemporary Society}

During the reign of king Joram of Israel, the economic situation of Samaria was very bad that women had to be killing and eating their sons (2Kings 6:28-29). But when Elisha prophesied a rapid economic boom for Samaria, a faithless officer of the King doubted and said even if the Lord should open the floodgates of the heavens an economic boom cannot be experienced in Samaria (2Kings7:2). However, through proactive and discretionary faith, four lepers took a step that changed the misfortune of Samaria (2Kings7:2).

Nigeria is going through the experience of Samaria at present. The Country is the only OPEC member that is in the list of the poor nations. There is an endemic poverty, hunger, insecurity and total collapse of all national infrastructures (Ekundayo, 2011). The nation currency has fallen to the level of \#164 to the dollar. The unemployment rate rose from 12\% in 1999 to $30 \%$ in 2010 and to $49.7 \%$ in 2013 (Aluko, 2010). The incidence of poverty is as high as $70 \%$ in the Northern Nigeria, while about $60 \%$ of the Southern Nigeria is enmeshed in poverty. About 64 to $70 \%$ of Nigerian population lives on less than US \$2 per day (Wikipedia, 2013).

Socially, Nigeria has become a Pandora's box of galling crimes, such as: corruption, dishonesty, drug trafficking, child trafficking, armed-robbery, Kidnapping, smugglings, local and international prostitution, 
thuggish activities, assassination, ritual killings, ritual raping of the under age children, and terrorism (Ekundayo, 2011). This situation has turned the nation into a land of horror for the citizens. Yet, no matter the

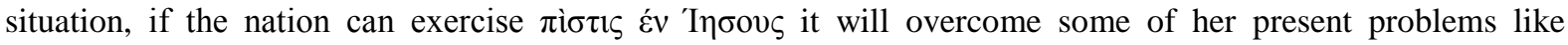
Samaria.

\section{Conclusion}

The exegetical exposition of $\pi \mathrm{i} \sigma \tau 1 \varsigma$ in John 14:12, shows that there is no difficulty or problem that

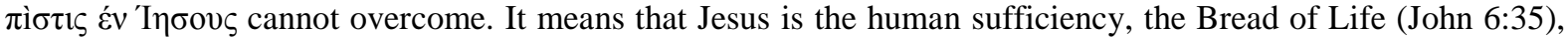
the way and the truth and the life (John 14:6), the good Shepherd and the Lamb of God (John 1:29) etc. The socio-economic and security situations of the African nations may be worrisome and threatening. Hunger, joblessness, poverty and the brutalities in the society may be making lives awry for people. Our nation may be

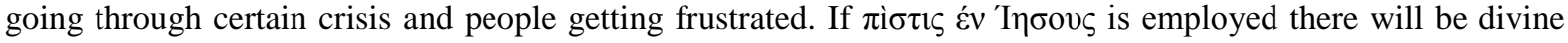
intervention in the continent of Africa.

\section{References}

[1]. Aluko, S. A. (2010). The cost of democracy in Nigeria since 1999. Nigeria: Victory Printing Press

[2]. Bruce, F. F. (Ed.). (1973). Life Application Bible, New International Version. U.S.A: International Bible Society.

[3]. Bruce, F. F. (Ed.). (1986). The International Bible Commentary. U.S.A: Zonderva Publishing House.

[4]. Cooper, A. (2013, Dec. 23). The Christian love. Retrieved from http://www.bible.truth.org.

[5]. David, P. (2013, October 12). What is real Faith? Retrieved from http://www.rcg.org.

[6]. Ekundayo, L.O. (2011). Leadership Factor in National Socio-Economic Development and Building: A Biblical and Contemporary Perspective. International Journal of Social Sciences, 3, (2), 182-193, Accra: Kandid Gold.

[7]. Ekundayo, L.O. (2011). Economy and Management: A Lucan Eco-Theological Approach to the Economic Situation of Nigeria. International Journal of Humanity, 3, (2), 36-41, Accra: Pan-African Book.

[8]. Faithmechanic, (2013, Dec 9). The Bible hope. Retrieved from www.hopefaithprayer.com

[9]. Matthew Henry's Commentary on the Whole Bible. (1992). U.S.A: Hendrickson Publishers.

[10]. Mary, F. (2014, January 3). What is Faith. Retrieved from http://www.christianity.about.com.

[11]. New Bible Commentary $21^{\text {st }}$ Century Edition. (1997). U.S.A: Inter-Varsity Press.

[12]. New Dictionary of Theology. (1988). U.S.A: Inter-Varsity Press.

[13]. Robin, K. (Ed.). (1983). The Lion Handbook of Christian Belief. England: Albatross Books.

[14]. United Church of God. (2013, December 20). Christian Faith. Retrieved from http://www.ucg.org.

[15]. White, E. G. (2002). The Desire of Ages. U.S.A: Harvest Time Books.

[16]. Wikipedia, (2013, December 23). The Economy of Nigeria. Retrieved from http:// www.en.m.wikipedia.org. 